\title{
THE ARCHITECTURE IMMANENCY AND PLACE ATTACHMENT CASE: AGA KHAN AWARD FOR ARCHITECTURE LOCAL MOSQUES WINNING PROJECTS
}

Received July $28^{\text {th }}, 2020 \mid$ Accepted September $11^{\text {th }}, 2020 \mid$ Available online December $15^{\text {th }}, 2020 \mid$ DOI http://dx. doi.org/10.18860/iia.v6i2.10043

\section{Eko Nursanty}

Department of Architecture

Faculty of Engineering

Universitas 17 Agustus 1945 (UNTAG)

Semarang, Jawa Tengah, Indonesia

santy@untagsmg.ac.id

\section{Muhammad Fahd Diyar Husni}

Department of Architecture

Faculty of Engineering

Universitas 17 Agustus 1945 (UNTAG)

Semarang, Jawa Tengah, Indonesia

husni@untagsmg.ac.id

\begin{abstract}
People are conducting their daily activities in Architectural space. The local community, which uses and gives meaning to that locality, turns the area into a place. Place Attachment is the place that has an emotional connection with the users. This research aims to identify the types and the roles of Place Attachment concerning the local community's religious needs, particularly the Muslim community. This study employs a qualitative research method by deductive literature review and big-data analysis to determine the emotional bonding manifested in the local community mosques' cultural immanence. The study looks into three Aga Khan Awards for Architecture winning projects to qualify the cases as a promising architecture selected by standard criteria. It discovers several tangible and intangible architectural elements inherited from generation to generation within a community, instituted on their sense of religiosity and the basic human need to connect with their Creator. Place Attachment strength and the uniqueness of architectural manifestation are directly related to those elements' immanency and regarded as the inherited DNA of a community.
\end{abstract}

KEYWORDS:

place attachment; place-making; Immanence; Aga khan award

\section{INTRODUCTION}

Aga Khan Awards for Architecture (AKAA) is recognition for architectural design achievements initiated by Prince Aga Khan IV in 1977. This program aims to identify and appreciate architectural concepts that successfully fulfill the Muslim community's needs and aspirations in contemporary design, social housing, community development, restoration, adaptive reuse, urban conservation, landscape design, and environmental improvements [1].

Referring to the place where people often use their place of worship as part of their daily life, local mosques become an indispensable part of the local community's place attachment in physical and nonphysical comfort. From individuals to government, clients commissioned most of the mosques built in the last twenty-five years around the world.

The concept of 'Architecture Immanency' becomes essential because a worship place is not built to increase the users' sense of faith. However, the worship place architecture is designed and built based on the sense of faith that is already owned by the community and becomes a public space that can provide peace and serenity according to their needs as a place with religious functions.
The research intention is to discover the functional and formal aspects and their interrelationships of the mosque architecture and its social, cultural, ideological, and environmental contexts. We chose to focus on project, debate, and current affairs that formed the architectural discourse and praxis in the countries with a Muslim majority and diasporic Muslim community as represented in the three projects that won the Aga Khan Awards for Architecture.

This study's topic is raised and disputed because the meaning of a mosque as a worship place for Muslims is no longer only concerned as a formal worship place with a demand for a clean and comfortable, but also as a virtual public space for the community in the surrounding. The first hypothesis about how important the role of the relationship between the mosque to a local environment and the community around it, then the answer can be found in the literature reports on the construction of local mosques that received the Aga Khan Award. The Aga Khan Award has shown evidence that architecture, especially in some mosques, was built passionately by the community after going through a very long process to prove their affection for the mosque as a virtual public space from time to time. 
The selection of research cases was carried out on the objects of mosques to answer research questions, as follows; (i) Is there any axis and symmetrical concept that exists in a local mosque, which initially was the only land that was donated by one of the residents that developed it step by step so it can meet architectural comfort standards? (ii) Is the visual symmetrical axis in local mosques always in line with the user's vertical axis and its Creator? (iii) What about a mosque with a more dominant function as a public space? Can the dominance be reversed? These criteria were tested on mosques that have received the Aga Khan Award, based on the testimony of several parties, both the architect, the owner of the mosque's initial establishment and the public testimony.

The other important aspect is the client's or the designer's concept found in the Awards project dossier, the living relationships between the community, public space, and architecture. There we can see the harmonious connections from the past to the present. Aga Khan Awards program has been able to support and protect the architectural forms and the architecture of freedom and justice. The Awards aspired to safeguard the built environment's quality concerning its deep and productive relationships with this living planet [2]

\section{RESEARCH METHODS}

The qualitative method is applied to the data collected through comprehensive online and offline literature reviews from books, journal articles, mass media publications, and other relevant resources related to Aga Khan Awards for local mosques that became the focus of this study.

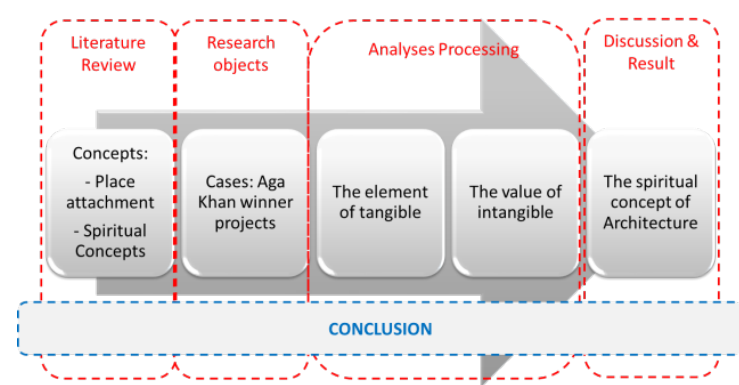

Figure 1. Qualitative Research method with a deductive approach [the author]

A literature review is a systematic and structured research methodology to find novelties according to the research objectives [19]. Therefore, this paper provides a description, summary, and critical evaluation of the past projects on whether Aga Khan Awards winning projects could enhance the value of place attachment for increasing the quality of human life.

Figure 1 above illustrates the deductive process based on the grand theory on place attachment, implemented on the Awards winning local mosques located in the high density and low-income areas according to the architect's briefs. The analytical process is carried out by looking from both emotional and rational aspects (right and left sides of the human brain) in examining the role and function of a place [20].

The research method used in data collection during the research process was carried out using literature studies, scientific papers, and documentary films owned by Aga Khan, which have been widely published, as primary data. Meanwhile, secondary data collection uses big internet data in the form of social media, and so on. The collected data were analyzed using the interpretative qualitative analysis method and using the place attachment theory to investigate the relationship between place and its people's emotional bond.

\section{RESULT AND DISCUSSION}

The impact of place on human life and their livelihood will become more resilient if their past experiences support it and continuously maintained and nurtured for the sake of the future generations.

\section{PLACE ATTACHMENT AND SPIRITUAL CONCEPT}

The impact of place on human life and their livelihood will become more resilient if their past experiences support it and continuously maintained and nurtured for the sake of the future generations [3]. Therefore, individual attachment is a personal feeling over the place, although often, the meaning of not being realized by the local community's daily life.

It is a fact that visitors are interested in a distinctive location due to what they think has a unique place meaning. Often, an individual's attachment to a place can be easily shared by the local community, such as customs, beliefs, religious practices, and intangible cultural heritage, as manifested in the geographical space [4]. This condition turns space into "a place," as reflected in the idea where the social role contributes to the level of the individual's attachment to a place. On the other hand, place attachment can be regarded as the embodiment of positive emotional bonding between the individuals to their social-physical environment [5].

Some earlier studies focused on the relationships between geography, human, and social psychology, that measured the general structural relationship in place attachment based on place identity and dependence of individuals and their environment [6]. The definition of the place identity above results from specific values, behavior, and belief related to the physical context [7]. The place dependency is regarded as the attachment to a place due to functional reason, which is the fulfillment of the individual's particular activity.

The Aga Khan Awards three winning projects collectively responded to the need to restore the balance between arts and Islamic Architecture. It is only recognized through the great traditions to question the ethos of individual creative genius, avoid formal criteria of excellence, and understand the relationships 
between arts and Islamic Architecture. Furthermore, understanding the above connections is expected to bring us to the broader knowledge of the relationship between faith and community.

As discovered from research about signs and symbolism in Islamic Architecture, the absence of unique visual Islamic symbols or Quranic iconography did not affect the importance of Islamic architecture meanings. It does not depend on formally codified language but on the texture of life itself [8]. Moreover, Aga Khan Awards is continuously looking to extend the architectural mission beyond individual building into the entire settlement, infrastructural network, and building system by emphasizing the process instead of the product. It is prompted us to reconsider the customary relationship between architecture and the community in standard conditions or under extreme demographic and poverty pressures [9]. From the tourism perspective, some researchers elucidated the understanding and application of Place Attachment through festivals that promoted interactions between the local community and tourists in strengthening the emotional bond with a place [10]. The uniqueness and the difference of visual language of Islam in mosques are explained in an essay "On Mosque Architecture" (mihrab, minaret, gateway, guardhouse, portico, ablution space, flooring, and dome), followed by a call for a further inventory of other Islamic building typologies [11]. The other part of the essay states that the conceptual relationship between modernity and Islamic premises has not been sufficiently uncovered or remained an abstract notion. The mediation between intellectual construe, spatial experience, and contextualization to a specific culture and location, have not been explained. It is, according to the author, the challenge for contemporary architecture. Thus, the three case studies' choice is based on their formal design narrative and religious symbolical meanings, as illustrated in Figure 2.

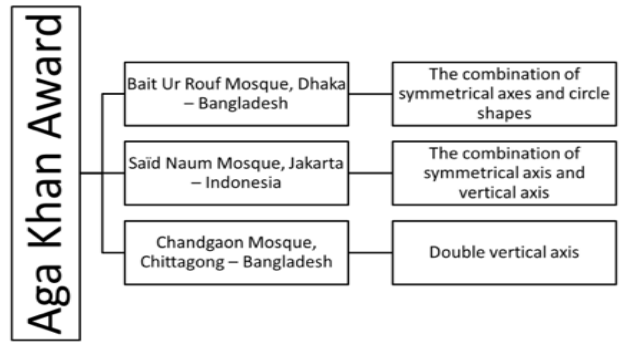

Figure 2. Aga Khan Awards as the reference for cases selection [the author]

\section{BAIT UR ROUF MOSQUE, DHAKA - BANGLADESH}

Bait Ur Rouf Mosque di Dhaka, Bangladesh, is an example of where the Awards was given to solve environmental issues related to the tropical climate and public space in a sustainable environment. This town mosque is located in the middle of a lower-middle economic class community in Dhaka, designed by a Bangladeshi architect, Marina Tabassum, completed in 2012. With the beautiful interplays of natural lighting, this place is well known as a spiritual sanctuary in urban Dhaka. The Awards also recognized this as a local mosque that challenged traditional mosque design [12].
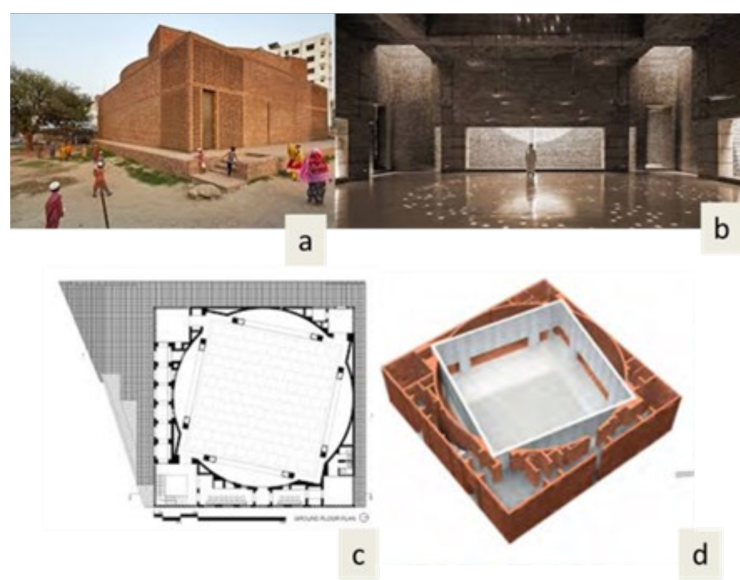

Figure 3. (a) Bait Ur Rouf Mosque Dhaka Bangladesh. Architect: Marina Tabassum (b) Interior (c) Plan (d) Isometric

Figure 3 shows that the mosque does not have traditional symbolisms such as the dome and minaret commonly used. Instead, it emphasizes the open space and elaborate interaction between light and shadows to create a prayerful space that uplifts the spirit.

Baitur Rauf Mosque is built in an increasingly dense settlement in Dhaka. The mosque is oriented to Qibla with 13 degrees angle in an innovative negotiation with the site design. A cylindric volume is placed inside a square box to facilitate the prayer hall and form rooms of light on its four corners. The prayer hall is an elevated space with peripheral columns. Additional functions are organized inside the area in the cylindrical external alley space. The ground floor remains bright during the day, with playing children and chatting male elders waiting for the call for prayer. The mosque is financed and used by the local community and inspired by the Sultanate mosque. The building can "breathe" through porous brick walls, keeping the prayer hall well ventilated and comfortable due to proper cross ventilation-natural lighting entering from the skylight providing enough illumination during the day.

\section{SAÏD NAUM MOSQUE, JAKARTA - INDONESIA}

The mosque is named after the name of the benefactor who donated the land. The architecture of the mosque follows Hindu-Javanese traditional architecture, with adjustments to suit Islamic worship place. The plan of the main building is square and symmetrical, with a wide verandah around it. The mosque is located in the middle of the high-density middle-lower income population in Jakarta, surrounded by roads, housing, and a Madrasah. 

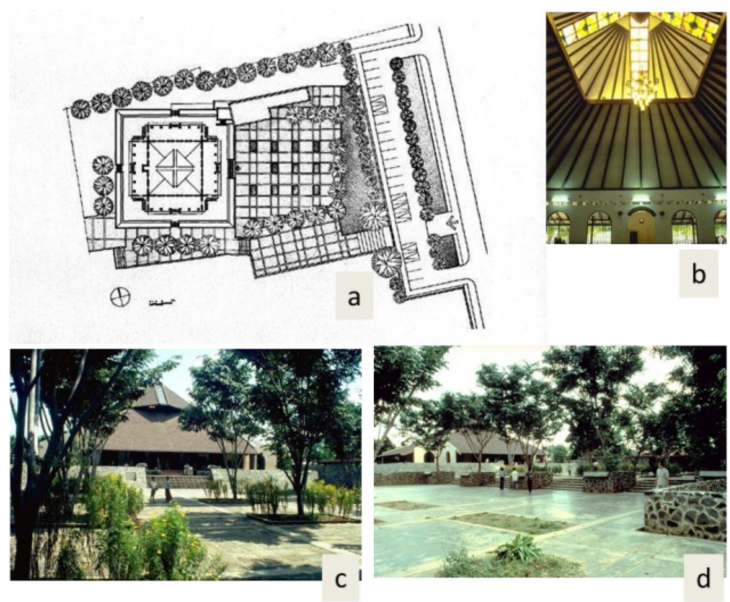

Figure 4. (a) Plan (b) Interior (c) Saïd Naum Mosque, Jakarta Indonesia. Architect: Adhi Moersid (d) Exterior

Traditional Javanese architectural idioms were reinterpreted, resulting in modern regional architecture and the best original design [13]. It is based on the most basic Javanese house typology, emphasizing the roof form ("Meru," or the pyramidal shape of a mountain), single or multiple tiered roofs, supported by four primary timber columns ("Saka Guru") as shown in Figure 4.

The architect, Adhi Moersid, deliberately took the the "Meru" roof typology, and without putting MiddleEastern style minaret. It is the most common religious building typology in Java before Islam arrives in Indonesia, such as the Hindu shrines in Bali that still exist until today. The "Meru" pyramidal roof form with a single tip has a sacred meaning for Indonesia's preIslamic culture. It is associated with a high point closer to the gods (heaven) above, like the mountain top. Vertically, the tip of the roof represents the "Axis Mundi" or the symbolic vertical axis that connects or transcends humans on earth and God the Creator in heaven. The architect cut the "Meru" at the middle and twisted 45 degrees, resulted in a double-tiered roof with edges oriented to the eight cardinal directions, symbolizing the omnipresent Creator [14].

Besides the roof, the sense of vertical centrality is highlighted by the abstract stained-glass motives, roof rafters' directions, and exposed purlins. The architect hanged a large chandelier under the rooftop as the focal point to emphasize the prayer space's centrality. The pyramidal shape is related to the philosophical meaning, but it is also a response to Jakarta's high tropical rainfall. World Meteorological Organization recorded $1,633 \mathrm{~mm} /$ inch annual rainfall for Jakarta. The steep roof is the most suitable form to quickly washdown the rainwater to the drainage system [15].

\section{CHANDGAON MOSQUE, CHITTAGONG - BANGLADESH}

With its strikingly pure white color, the Chandgaon mosque stands out among the non-conventional mosque architectural design features. As can be seen from Figure 5 below, it makes a clear statement on different directions of the architectural design concept, expressing the intention to live in the space that embedding the contemporary universal values [16].

The mosque location is at the edge of Chittagong harbor in Bangladesh. It tries to fulfill the traditional role of a spirituality center and community gathering place. In articulating a new form, the architect started identifying the essential elements of a mosque. It is done by resurfacing the typology that has been existing for one and a half millennium. The result is a monolithic mosque with two identical cubical structures [17]. The first domed part is the front courtyard surrounded by massive stoned walls with low and wide openings towards the surrounding landscape, with an opening like eyelashes on the top. The second part has an iconic dome frustum for natural lighting. This void gives a sense of openness; during the day, it draws light and ventilation in, while at night, the light from inside beamed out like a lighthouse [18].

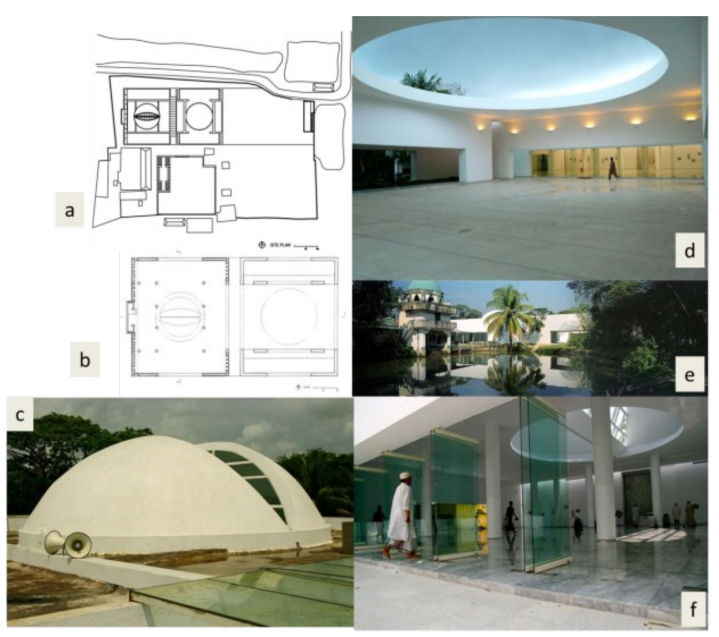

Figure 5. (a) Site plan (b) Plan (c) Perspective (d) Interior under the dome (e) Exterior (f) interior Chandgaon Mosque, Chittagong - Bangladesh

\section{THE DNA OF PLACE ATTACHMENT}

Place attachment concerns the relationships between people and their living place. Since the beginning of the 1980s, places like home, religious sites have been considered locations that possess place attachment and unique emotional bonding with its community [21]. 


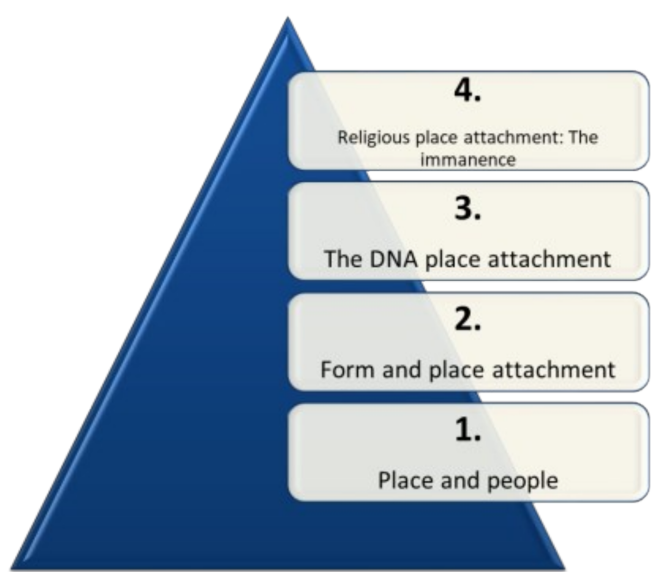

Figure 6. Hierarchy of place attachment in religious buildings [the author]

Migration influences the changes and causing instability to the community's dynamics. People adapted to a new situation by creating a "new" culture and the existing local culture. Nevertheless, the concept of place attachment remains to focus on the relationship between people and their activity place.

In Figure 6, the place and people in position one at the bottom of the triangle show its fundamental role in the following hierarchy. The population movement and migration are happening in big cities worldwide, such as Dhaka, Jakarta, and Chittagong, especially in the high-density areas where those mosques are located.

The sacred place has a firm place attachment potential; it is a place for worship and a place for the people to do various communal and social activities, gather and wait for the call for prayer. Here is where the second tier in the hierarchy of form and place attachment is placed.

The unique functional transformation or development within the local community is influenced by the decisions concerning the use of space agreed by them from generation to generation continuously. It is called the city DNA [22]. The DNA of place attachment can be found primarily in religious buildings, as seen from the three mosque cases. According to the research finding, local mosques did not use the dome as the sign to represent main-stream mosque expression. Still, they used a unique character known by the local community from generation to generation, as placed at level 3 in the diagram above.

In the assimilation process of the architect's design ideas and community's opinion, the cultural acculturation of local culture with the religious values was manifested into the design, such as (i) the usage of beautiful natural lighting to challenge the traditional mosque design status quo in Bait Ur Rouf Mosque, Dhaka; (ii) the use of the tiered roof with extended ridges symbolizing the omnipresent of the Creator in
Said Naum Mosque, Jakarta; (iii) the usage of identification elements on the new form to represent the contemporary concept of universal values in Chandgaon Mosque, Chittagong. This process is positioned at level 4 in Figure 6 above, which is the religious place attachment, or the immanence of place.

\section{SPIRITUAL CONCEPTS}

Religion is essential for individuals and communities, which influences lifestyles, such as food preference, clothing, partners, house, environment, place of worship, public meeting, and collective participation [23]. The spiritual concept implemented in the three local mosque cases is contextual to the place and the perception of sacredness in where they live. The mosques were built with funding from the donation and collection from the community. It used local building materials with local architectural elements that were dominantly expressed in the building façade. The spiritual concept is not divided according to special zones within the building but blended in spatial continuity. The internal lighting is unified with the external forms; the superficial appearance of the exterior blends with the settlement and the living environment.

The rise of religious ideology and a sense of nationalism have been growing in cities around the world. The attempt to find identity has become a way to express their self-confidence and pride as local and faith owners. Thus, the spiritual concept is the manifestation of the community with the Creator of the place. It is also a reason for the rootedness of that particular place.

\section{FORMAL EMBODIMENT}

As has previously stated, place attachment appeared very strongly on places that are regarded as holy or sacred by the community, including the local mosques used as the research cases. In the previous study, there are several types of place attachment on sacred places: (i) attachment to natural landscape, (ii) attachment to holy cities, and (iii) attachment to architecture; the last one has two components: (a) attachment to religious architecture; and (b) attachment to home [24]. In the local context of all three mosques, spiritual attachment is manifested in the formal elements and mosque usage for communal activities.

The embodiment of a religious building's architectural work requires a place attachment process to increase the strength of place attributed to the Creator, the transcendence process. Transcendental is a literary term referring to the attribute of extracategory thing [25]. In philosophy, transcendence is the effort to convey the basic concept or the literal meaning of a word into a higher sense above others. However, the connotations can vary across different historical periods and different cultural contexts. It includes philosophies, systems, and approaches that describe the fundamental structure of beings, not as 
ontology (creation theory), but as a framework for the emergence and validation of knowledge about creatures [26].

The virtual axis is a formalization of transcendence in architecture. The human soul is a microcosmic manifestation of various possible external signs within himself. Recognition of an imaginary world is needed to place the spirit in sync with the cosmos. The "cosmos" here shows the entire universe and the perfect order inherently embedded in it. This condition is a unity of balance and deep harmony between various forces, events, and elements of concern to all ancient civilizations. Based on this cosmological scheme, the imaginary world's doctrine relates to an intermediate realm that connects this physical world with the world above and humans to a higher reality and ultimately to God. Concerning the Islamic world's architectural traditions, the imaginary world's idea plays a vital role because the architect's imaginative abilities can create and describe the form [27]. In architectural works, especially local mosques, the concept of transcendence is carried out by exploring in two perspectives, namely: traditional ideas that originate from sacred values "outside visible from" and alternative concepts where sacredness originates from beings seen in a place [28]. Each of the perspectives above is evaluated from the viewpoint of aesthetics and hierarchy. Both forms of transcendence above are considered necessary for the fullness of religious life.

\section{IMMANENCE PLACE ATTACHMENT}

The relationship between transcendence and immanence has been studied over a long period in the field of philosophy, where both have different tendencies in the realm of reality (tangible) and ideas (intangible) [29]. Figure 7 illustrates some of the intangible axis-forming elements formed from several local architectural elements in the community's middle, where the building is located. The Q-axis is the prayer direction, which is commonly understood as the Qibla direction of Muslim prayer towards the Kaaba.

The vertical axis ( $\mathrm{Va}$ ) is created by the openings in holes of light from above. It is also a means to admit natural lighting during the day, as well as vertical transference. In this conceptual scheme, "transcendence" describes both the metaphysical structure that underlies the contingent on God the Creator and the practical spiritual search for overcoming changes in worldly affairs towards the final and eternal union [28].

In this perspective, something that is limited, temporal, and contingent cannot stand alone without meaning and absurdity. At a later stage, basic platonic questions will have no answers, and our existence has no direction or purpose.

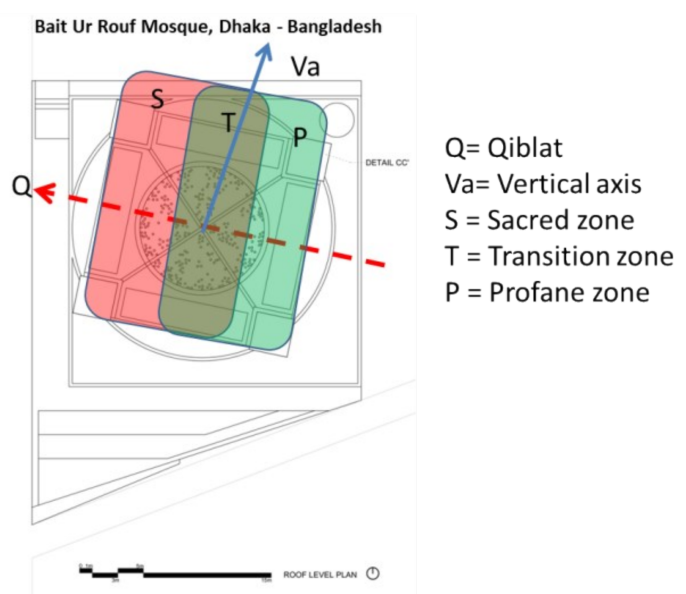

Figure 7. The horizontal and vertical axis in Bait Ur Rous Mosque [the author]

Figure 8 illustrates that the axis on the Q (Qibla) axis at the Saïd Naum Mosque, Jakarta, is the mosque's central axis and is perpendicular to the main road serves as the main entrance towards the mosque. The vertical axis ( $\mathrm{Va}$ ) is manifested in the form of a prominent roof's rafters. It represents God's transcendence, even though the roof rafter is influenced by Hinduism that existed before Islam came to Indonesia. In the unification of the mosque's place of attachment, God the Creator, and the mosque's community, the acculturation process manifested in formal transcendence is not in conflict with the immanence.

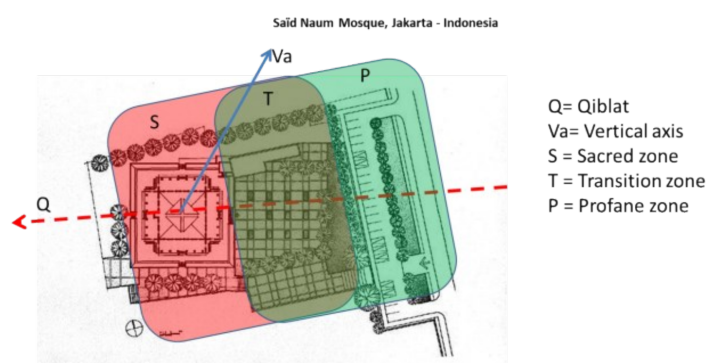

Figure 8. The horizontal and vertical axis in Saïd Naum Mosque, Jakarta - Indonesia [source Nursanty, 2020]

Figure 9 illustrates the existence of two vertical axes in the Chandgaon Mosque, Chittagong. One building with vertical axis 1 (Va1) is located in a room with glass-enclosed walls to become a transparent wall. In contrast, the second vertical axis ( $\mathrm{Va} 2$ ) is situated in a directly connected space to outer space. The Q-axis or Qibla direction is parallel to the main road in front of it. Lighting and humility are immanence elements united with the need for transcendence to God the Creator and become dominant with two similar and close forms like the eye. 


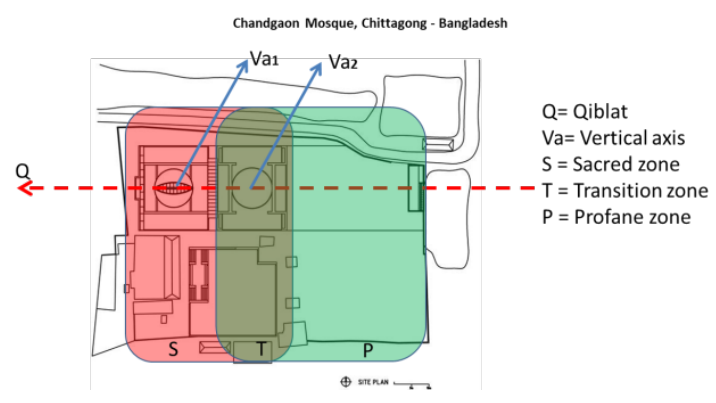

Figure 9. The horizontal and vertical axis in Chandgaon Mosque, Chittagong - Bangladesh [the author]

Open space in the offensive zone was expanding the main room and expressed as a link between the building and the surrounding community to carry out activities both as a community and individually in practicing their faith.

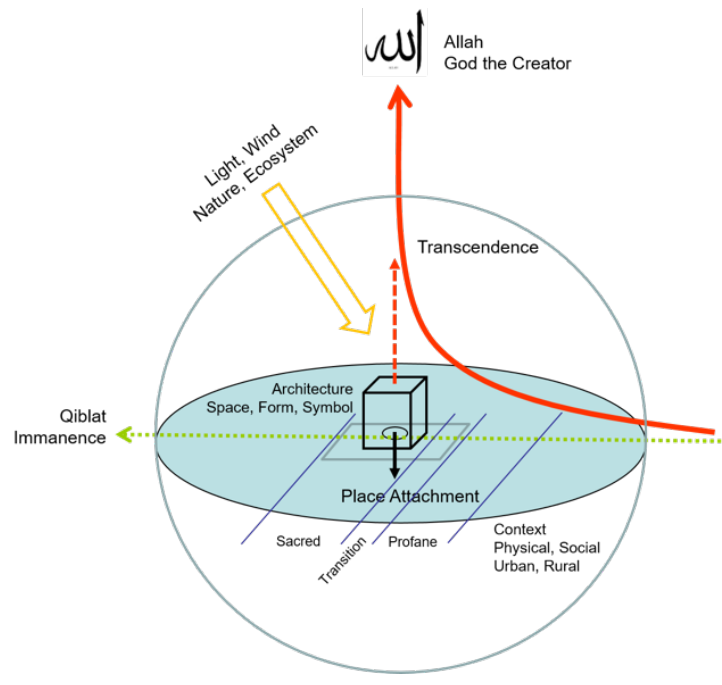

Figure 10. Transcendence and immanence in architectural manifestation

Figure 10 illustrates the relationship between the transcendence and immanence elements arising from the 3 (three) specifically revealed previously, in the form of (i) Vertical axis is a manifestation of the need for closeness with the God the Creator, is presented in the form of an opening to enter natural light, natural air and open space for the required natural flow and emission; (ii) The Qibla axis is always the central horizontal axis in the interior, but it is not always the axis for the function space hierarchy of the sacred zone transition zone - offensive zone; (iii) the place attachment context of a building is strongly influenced by the physical form of a location in a dense urban area and a common form of a community that symbolizes the spirit of being a universal Islamic family ("Ukuwah Islamiyah").

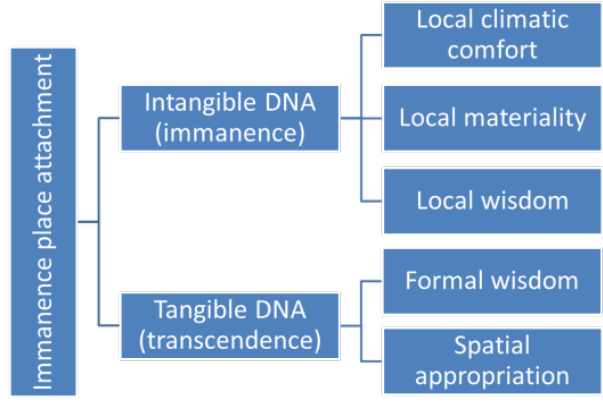

Figure 11. Components of Immanence immanency of Place Attachment [the author]

Figure 11 illustrates two elements of the central concept of immanence and transcendence found in the three cases, related to its place attachment. The intangible immanence is formally manifested in adaptation to the local climate and building materials in the building. Simultaneously, the transcendence element that can be identified is local wisdom and spatial appropriation in public space for the community and its environment. The elements' selection can be recognized because their form and application are carried from generation to generation and become typical DNA, which is carried out repeatedly from previous generations to the next generation, where the overall position of this Immanence Place Attachment in this study is depicted in Figure 12 below as a result of the research findings.

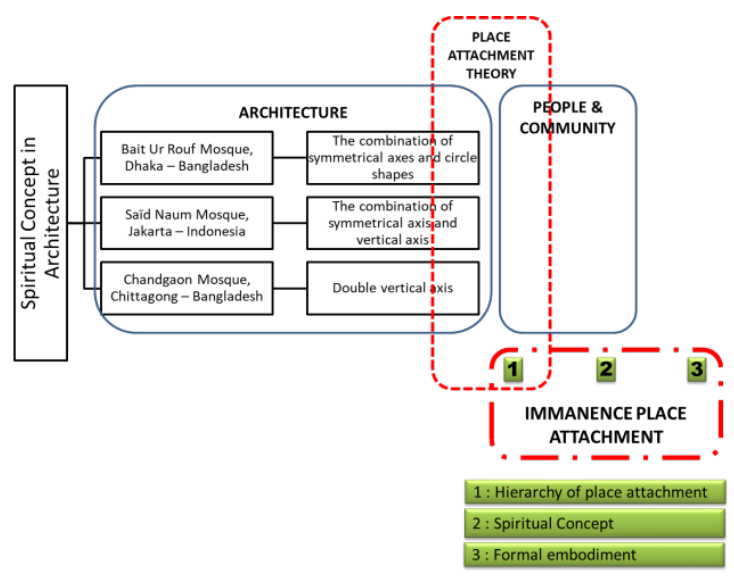

Figure 12. The process spiritual concept if Architecture of Immanence of Place Attachment [source Nursanty, 2020] 


\section{CONCLUSION}

The three case studies of Aga Khan Awards, winning new local mosque projects have provided us with a clear understanding of the real relationships of faith with nature and community in Architecture.

The sense of religiosity and their lives' dailiness is manifested through the tangible and intangible architectural elements. It is a kind of "DNA" inherited from generation to generation within a community and attached to a place. The strength of the place attachment and architectural manifestation's uniqueness is directly related to the transcendence and immanence process. Qibla direction is not just the prayer direction towards Mecca that unified the Muslim community in universal brotherhood, but also an intangible transition of spatial zoning from profane to sacred that can only be experienced internally through faith (immanence). While the sense of connection with God, the Creator can be achieved through the verticality by tangible forms (openings, sunlight, roof tip, etc.) that transcend the human mind and heart to the height of their consciousness.

The firm places attachment to the social (community), physical (site, city), and natural contexts are achieved through cross ventilation, natural lighting, ornaments, site-planning, landscape design, and architectural articulations. The bodily experience, combined with the spiritual imagination of transcendence and immanence, makes up the complete set of the totality of human-centered Architecture. The lessons learned from the study are useful for the discourse in architectural theory and design by enlighting a new understanding about the importance of place attachment, transcendence process, and immanency in successful and meaningful mosques architecture. It goes beyond the modernist design idiom of "form follows function" and the importance of a community-centered design process.

Further research can be done to include more case studies of mosques in different contexts and levels. Further discussion and continue the debate in Islamic Architecture, Religious Architecture, Genius Loci, Place attachment, Local Wisdom, and related topics.

\section{REFERENCES}

[1] S. Bozdogan, "The aga khan award for architecture: A philosophy of reconciliation," J. Archit. Educ., vol. 45, no. 3, pp. 182-188, 1992.

[2] Ş. Yücel, "The Aga Khan Award for Architecture," Int. J. Islam. Archit., vol. 7, no. 1, pp. 207223, Dec. 2017.
K. M. Woosnam, K. D. Aleshinloye, M. A. Ribeiro, D. Stylidis, J. Jiang, and E. Erul, "Social determinants of place attachment at a World Heritage Site," Tour. Manag., vol. 67, pp. 139146, 2018.

[4] N. I. M. Rodzi, S. A. Zaki, and S. M. H. S. Subli, "Between Tourism and Intangible Cultural Heritage," Procedia - Soc. Behav. Sci., vol. 85, pp. 411-420, 2013.

[5] R. C. Stedmanl, "Sense of place as an indicator of community sustainability, Sustainability of Forest Communities - What," Forestry, vol. 75, no. 5, 1999.

[6] D. D. White, R. J. Virden, and C. J. Van Riper, "Effects of place identity, place dependence, and experience-use history on perceptions of recreation impacts in a natural setting.," Environ. Manage., vol. 42, no. 4, pp. 647-657, 2008.

[7] H. M. Proshansky and A. K. Fabian, "The Development of Place Identity in the Child," Spaces Child., pp. 21-40, 1987.

[8] R. Othman and Z. J. Zainal-Abidin, "The importance of Islamic art in mosque interior," Procedia Eng., vol. 20, pp. 105-109, 2011.

[9] K. M. Woosnam, K. D. Aleshinloye, M. Strzelecka, and E. Erul, "The Role of Place Attachment in Developing Emotional Solidarity With Residents," J. Hosp. Tour. Res., vol. 42, no. 7, pp. 1058-1066, 2018.

[10] R. Sharpley and D. Jepson, "Rural tourism A spiritual experience?," Ann. Tour. Res., vol. 38, no. 1, pp. 52-71, 2011.

[11] A. S. Ismail, "The Influence of Islamic Political Ideology on the Design of State Mosques in West Malaysia (1957-2003)," Fac. Built Environ. Eng., vol. Doctor of, no. September p. 480, 2008.

[12] A. Grigorieva, "International Architecture News," Proj. Baikal, vol. 13, no. 50, pp. 5-5, 2016.

[13] M. S.- Itb and K. Ahmad, "Pengaruh Modernisme terhadap Aplikasi Ragam Hias," vol. 3, no. 1, pp. 11-24, 2009.

[14] H.-U. Khan, "The Architecture of the Mosque, an Overview and Design Directions," Expressions Islam Build., pp. 109-127, 1990.

[15] Bagoes Wiryomartono, "Tinjauan Buku ‘Kagunan' Karya Arsitektur Adhi Moersid,” J. Seni Rupa Warn., vol. 4, no. 2, pp. 223-233, 2015.

[16] A. Mia, S. Nasrin, M. Zhang, and R. Rasiah, "Chittagong, Bangladesh," CITIES, vol. 48, pp. 31-41, 2015.

[17] Elizabeth A. Sibilia, "Market Making: Crises and The Global Production of Shipbreaking in Chittagong, Bangladesh," 2019.

[18] A. Sarraz, K. Ali, and D. C. Das, "Seismic Vulnerability Assessment of Existing Building Stocks at Chandgaon in Chittagong city, Bangladesh," vol. 3, no. 1, pp. 1-8, 2015.

[19] C. Okoli and K. Schabram, "Working Papers on 
Information Systems A Guide to Conducting a Systematic Literature Review of Information Systems Research," vol. 10, no. 2010.

[20] E. Nursanty and L. Muhamadi, "Holistic pedagogy for nurturing faithful, resilient and empathetic students - in UNTAG Semarang architectural education," SARGA J. Ilm. Arsitektur dan Perkotaan., vol. 1, no. 1, pp. 6-14, 2019.

[21] B. Hernández, M. Carmen Hidalgo, M. E. Salazar-Laplace, and S. Hess, "Place attachment and place identity in natives and non-natives," J. Environ. Psychol., vol. 27, no. 4, pp. 310-319, 2007.

[22] E. Nursanty, "The anatomy of place branding: relating place transformation to community identity," Place Brand. Public Dipl., no. Gotham 2002, 2019.

[23] S. Mazumdar and S. Mazumdar, "Religion and place attachment: A study of sacred places," J. Environ. Psychol., vol. 24, no. 3, pp. 385-397,
2004.

[24] S. S. S. S. Mazumdar and S. Mazumdart, "Sacred Space and Place Attachment," Water, vol. 13, no. 3, pp. 231-242, 1993.

[25] N. A. Friesner, "A transcendentalist nature religion," Religions, vol. 8, no. 8, 2017.

[26] M. Lozanovska, "Hagia Sofia (532-537AD): A study of centrality, interiority, and transcendence in architecture," J. Archit., vol. 15, no. 4, pp. 425-448, 2010.

[27] F. Nasrollahi, "Transcendent Soul of the Muslim Architect and Spiritual Impact of the Islamic Architecture: Islamic Architecture and mundus imaginalis," J. Islam. Stud. Cult., vol. 3, no. 2, pp. 86-99, 2015.

[28] Ursula Goodenough, "Vertical and Horizontal Transcendence," vol. 36, no. 1, pp. 21-31, 2001.

[29] M. Rölli, "Bulletin de la Sociite Amincaine de Philosophie de Langue Immanence and Transcendence," vol. 14, no. 2, 2004. 